\title{
O "DIA DELÍRIO" DE MACHADO DE ASSIS E AS FESTAS DA ABOLIÇÃO
}

\section{RENATA FIGUEIREDO MORAES}

Universidade do Estado do Rio de Janeiro

Rio de Janeiro, Rio de Janeiro, Brasil

Resumo: O texto aborda a participação de Machado de Assis nos festejos pela Abolição - missa, cortejos e poesia -, estando também entre aqueles que produziram uma memória para o grande feito do 13 de maio: o fim da escravidão. Se os relatos sobre a Abolição tratam sempre de um "delírio" machadiano, nem sempre abordam as diferentes funções desse literato para o processo, tendo sido funcionário público desde 1873, cargo em que atuou pela liberdade dos escravos, e, em 1888, também um intérprete da abolição, através das crônicas e poesias. As festas da Abolição ficariam na memória desse literato que nos anos seguintes usou esse "dia de delírio" para comentar o seu presente republicano e o futuro das festas da Abolição.

Palavras-chave: Abolição; República; festa; Machado de Assis; Rio de Janeiro

\section{THE "DAY DELIRIUM" OF MACHADO DE ASSIS AND THE CELEBRATIONS OF THE ABOLITION}

\begin{abstract}
The text addresses Machado de Assis's participation in the Abolition celebrations - mass, courtship, and poetry - as he was among those who created a memory for the great feat of May 13: the end of slavery. Although the reports about Abolition always discuss a Machadian "delirium," they do not always address the different roles this literary figure played in the process, as he had been a civil servant since 1873, where he worked for the freedom of slaves, and in 1888, as an interpreter of abolition through chronicles and poetry. The festivals of abolition would be in the memory of this writer who in the following years used this "day of delirium" to comment on his Republican gift and the future of the Abolition celebrations.
\end{abstract}

Keywords: Abolition; Republic; celebration; Machado de Assis; Rio de Janeiro 


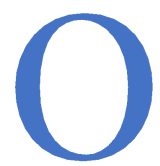

s relatos sobre a Abolição e a festa ocorrida no Rio de Janeiro em 1888 abordam euforia e delírios. A fim de "comprovar" esse último, uma frase de Machado de Assis é costumeiramente usada: "foi o único dia de delírio que me lembra ter visto". No entanto, como é comum entre escritos esparsos sobre esse literato, tal frase aparece fora de contexto e sem as referências de quando foi dita pelo autor. $\mathrm{O}$ "delírio" machadiano faz parte das comemorações pelo fim da escravidão, apesar de a frase não ter sido escrita em 1888. Esse artigo insere Machado de Assis nas festas da abolição e no processo de construção de uma memória para esse dia de delírio, quando será possível entender de mais perto o treze de maio de Machado de Assis.

A assinatura da lei da Abolição num domingo provocou uma organização da imprensa da Corte em torno das celebrações ao grande feito da lei: o fim da escravidão. Entre festas realizadas nas ruas e nos teatros da cidade, a própria imprensa se tornava um ambiente de celebração ao usar suas páginas para interpretar aquele dia. Entre tantos sentidos, colocavam o 13 de maio como a data da independência da Nação ${ }^{1}$ ou tendo o mesmo peso que o 14 de julho francês. ${ }^{2}$ Para Rodrigo Octavio, nessa data teria ocorrido a primeira festa nacional, celebrada pelo povo, e, para ele, a forma da festa teria uma função futura: "Na posteridade, a notícia desse entusiasmo delirante atenuará sem dúvida o horror da escravidão, tolerada por este povo até o fim do século XIX". ${ }^{3}$

A imprensa que celebrava o fim da escravidão era a mesma que abrigou no seu quadro de redatores grande parte dos literatos que mais tarde teriam seus nomes escritos no panteão literário brasileiro. Representantes de uma estética realista ocuparam as redações dessas folhas não apenas para produzir literatura, mas também para atuar como redatores de notícias diárias e do cotidiano da política nacional. Um desses jornais foi a Gazeta de Notícias, que abrigou Machado de Assis, Olavo Bilac, Coelho Neto, Guimarães Passos e Raul Pompeia, entre outros. ${ }^{4}$ Se durante o século XIX esses literatos se dividiram entre a escrita nos jornais e uma militância no movimento abolicionista, o fim da escravidão era o momento para que pudessem orientar também a organização da festa e os seus sentidos. Coelho Neto e Artur de Azevedo estavam entre os que participaram do trâmite burocrático, compondo a comissão da festa organizada pela imprensa fluminense.

\footnotetext{
${ }^{1}$ RABELO, Treze de Maio, p. 1.

2 REGADAS, 13 de Maio de 1888, p. 1.

3 OCTAVIO, 13 de Maio de 1888, p. 1.

${ }^{4}$ MELLO, A República consentida, p. 117.
} 
Uma série de eventos foram programados pela cidade, entre préstitos, atividades esportivas e bailes públicos e noturnos. Apesar de o abolicionismo não ter se associado à Igreja católica, nem ter tido um apoio mais efetivo dessa instituição no combate à escravidão, ${ }^{5}$ o primeiro evento que inauguraria os festejos pela Abolição seria exatamente um de caráter religioso: uma missa no campo de São Cristóvão, no dia 17 de maio de 1888. Diante da ideia de que houve um encaminhamento pacífico para o fim da escravidão, caminho esse incentivado pelos literatos da imprensa, fazia sentido a promoção de uma celebração religiosa a fim de deixar irmanados todos os diferentes sujeitos daquele processo em um mesmo patamar. As diferenças políticas e desavenças que permearam o processo abolicionista na década de 1880 pareciam se desfazer nesses tempos de celebração, sendo a missa um novo meio de "religar" esses sujeitos tão diferentes. Diante disso, um altar que pudesse abrigar a todos e mostrar sacralidade no ato da Abolição foi cuidadosamente arrumado pelos organizadores, que definiram previamente o local que cada um deveria ocupar nessa celebração.

Ao lado esquerdo do altar acha-se levantada uma tribuna de onde assistirão à missa Sua Alteza e seu augusto esposo. Em seguida a essa tribuna, há uma outra destinada à câmara municipal e à imprensa fluminense, que deve apresentar-se com o respectivo distintivo, a fim de ali ter entrada. Ao lado direito do altar levanta-se uma outra tribuna, destinada aos membros do ministério e do corpo diplomático. ${ }^{6}$

O altar da missa com suas tribunas era a representação da irmandade entre imprensa e Império. Além disso, tende a reforçar a igualdade na responsabilidade no processo da Abolição daqueles que atuaram não apenas no Parlamento, mas também na imprensa e nas ruas, seja convocando o povo a comparecer às manifestações pela Abolição, seja escrevendo poesias e promovendo eventos abolicionistas que condenavam a instituição escravista. Aqueles que subiram ao altar da missa deveriam ser sacralizados pelos que festejavam e que também tentavam tomar parte daquele evento e da imagem que se fazia dele.

Uma multidão compareceu ao evento no aristocrático bairro de São Cristóvão, levando consigo alguns enfeites para as festas: os estandartes das irmandades religiosas e das associações. A celebração também teria o seu registro feito por um fotógrafo, Antonio Luiz Ferreira, o mesmo que dias antes

${ }^{5}$ ALONSO, Flores, votos e balas, p. 127.

${ }^{6}$ DIÁRIO DE NOTÍCIAS, 17 maio 1888. 
havia fotografado o largo do Paço e a multidão que esperava a notícia da Abolição.?

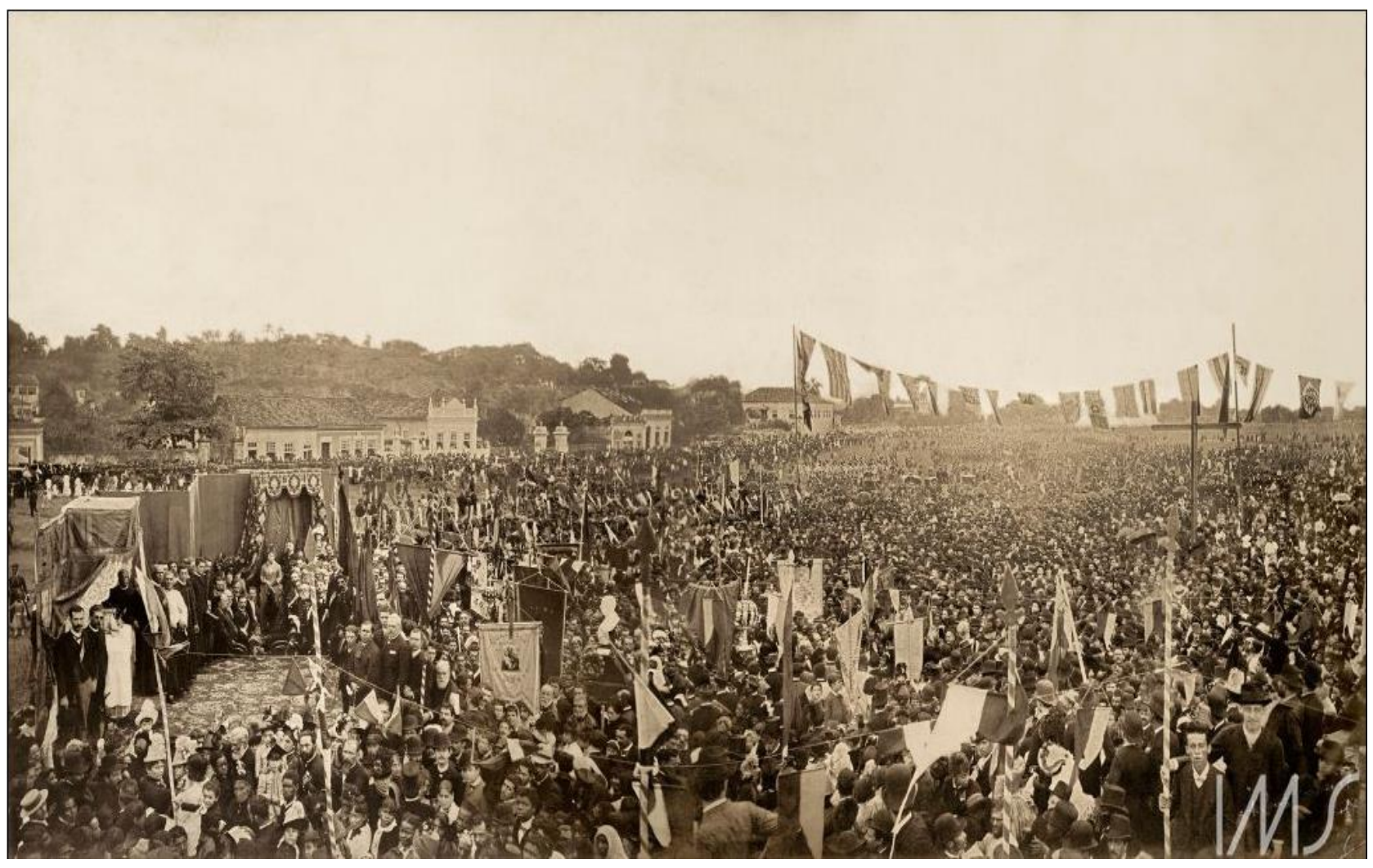

Figura 1 Antonio Luiz Ferreira, Missa campal celebrada no campo de São Cristóvão em ação de graças pela Abolição da escravatura no Brasil, 17 de maio de 1888 (Fonte: Instituto Moreira Salles, http://fotografia.ims.com.br/sites/\#1435691449677_17)

A imagem confirma o planejado a respeito de como seria o altar da missa. Ao fazermos um recorte da foto (Figura 2) a fim de analisar melhor o altar, é possível identificar que a princesa e o conde $\mathrm{D}^{\prime} \mathrm{Eu}$ aparecem entre dois grupos, a princípio distintos. Do seu lado direito, estavam os membros do gabinete que comandaram o projeto da Abolição: o conselheiro João Alfredo, o senador Thomaz Coelho e Rodrigo Silva. Do seu lado esquerdo, de acordo com o dito pelos organizadores do evento, estavam os representantes da imprensa. Nesse grupo, em destaque encontra-se Machado de Assis. O literato compunha o grupo da imprensa fluminense e representava ali aqueles que durante a década de 1880 atuaram em diferentes esferas contra a escravidão. Participar

${ }^{7}$ As fotos de Antonio Luiz Ferreira fazem parte da Coleção Princesa Isabel e foram publicadas em 2008 no livro organizado por Pedro Correa Lago e Bia Correa Lago. 
da festa, mesmo que num evento religioso, era uma forma de consagrar também seus companheiros das letras como conquistadores da liberdade para os escravos.

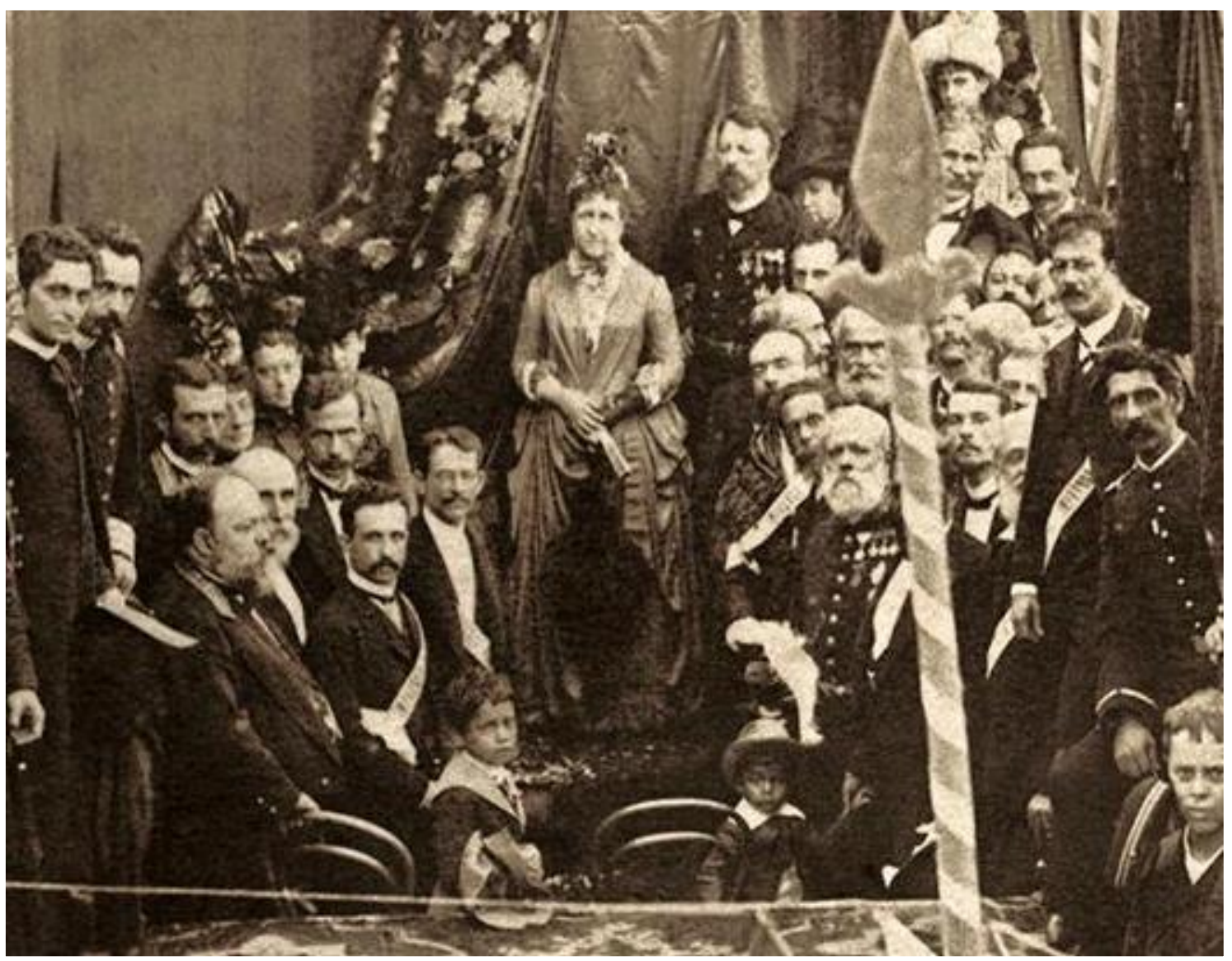

Figura 2 Recorte da figura 1

A celebração inicial dava o tom do que deveriam ser esses festejos: uma irmandade entre diferentes sujeitos que não mais teriam a escravidão para diferenciá-los. A missa servia para marcar o caráter redentor da lei sem relembrar o sacrifício da escravidão. Se no cristianismo a redenção apareceu após o sacrifício de um homem, o sofrimento dos escravos era o pano de fundo da redenção de toda uma nação, unida simbolicamente na missa. Pouco importava, naquele instante, que estivessem determinados os lugares sociais de cada sujeito no ato - marcados, na fotografia oficial da missa, na distância que separava o centro da ação, que estava no altar, do centro da imagem, focada no público indiferenciado. Nesse posicionamento ficava claro a quem caberia dirigir tal celebração e quem seriam os receptores da mensagem. 
Retrato fiel de uma sociedade baseada em hierarquizações, a missa e seu registro fotográfico representam, assim, a base de construção do futuro planejado para o Império brasileiro. Nesse futuro, os homens das letras tinham um papel fundamental porque era através deles que todo o sentido daquele momento seria sintetizado. Machado de Assis durante os dias de festa e nos anos seguintes até 1908, ano da sua morte, não deixará de escrever sobre a Abolição e o tempo da escravidão.

Essa primeira festa serviu de tema para a crônica machadiana. Em 1888 Machado de Assis assinava a série de crônicas "Bons Dias!", publicada na Gazeta de Notícias. No contexto da semana de festejos, um jornal especial foi criado para circular exclusivamente no fim da festa, na segunda-feira, dia 21 de maio. O jornal Imprensa Fluminense foi composto por textos de vários outros jornais, feitos especialmente para a publicação. Machado de Assis em sua crônica para o jornal especial abordou um evento religioso, que lembrou a seus leitores a missa em São Cristóvão testemunhada por ele do altar.

Em seu texto, Machado coloca o narrador atendendo aos pedidos para traduzir o evangelho lido na missa. Assim o faz numa paródia entre o texto religioso e os caminhos da Abolição, desde a saída de Cotegipe até a chegada de João Alfredo e a escolha dos demais membros do Ministério formado em março de 1888. O texto é todo escrito em versículos, sendo o primeiro algo semelhante ao Gênesis: "1. No princípio era Cotegipe, e Cotegipe estava com a Regente, e Cotegipe era a Regente" ${ }^{8}$

Os demais versículos seguem essa estrutura até chegar ao momento da assinatura da lei: "25. A Regente, que esperava a lei nova, assinou com sua mão delicada e superna". No seguinte, destaca a euforia e os "brados de contentamento" recebidos por João Alfredo e seus discípulos e a obediência dos senhores de escravos. Porém, no versículo 27, penúltimo, Machado de Assis salienta a recepção da lei numa província muito distante da Corte:

27. Menos no Bacabal, província do Maranhão, onde alguns homens declararam que a lei não valia nada e, pegando no azorrague, castigaram os seus escravos cujo crime nessa ocasião era unicamente haver sido votada uma lei, de que eles sabiam nada; e a própria autoridade se ligou com esses homens rebeldes.

\footnotetext{
${ }^{8}$ Essa crônica saiu no jornal Imprensa Fluminense. No entanto, utilizei a versão da crônica publicada no livro Bons Dias! organizado por John Gledson, porque o exemplar do jornal da Biblioteca Nacional se encontra mutilado, sendo possível ler apenas a metade da crônica.
} 
A denúncia vinda de um lugar tão distante talvez tivesse como intenção afastar da euforia existente na Corte a notícia sobre a permanência de alguns espectros da escravidão. Ora, no Maranhão a lei não chegaria de forma tão rápida, talvez devido à distância ou por conta das dificuldades das autoridades locais em aplicá-la. Na Corte, entre vivas e brados, teria sido diferente. No entanto, em seu último versículo, assim como o evangelho tenta dar um conselho, o cronista também quis dar uma lição e um desejo de futuro:

28. Vendo isto, disse um sisudo de Babilônia, por outro nome Carioca: Ah! Se estivessem no Maranhão alguns ex-escravos daqui, que depois de livres, compraram também escravos, quão menor seria a melancolia desses que são agora duas coisas ao mesmo tempo, ex-escravos e exsenhores. Bem diz o Eclesiastes: algumas vezes tem o homem domínio sobre o outro para desgraça sua. O melhor de tudo, acrescento eu, é possuir-se a gente a si mesmo.

A existência de libertos comprando escravos não parecia algo que admirasse o sisudo Carioca, que não parece ver mudanças nisso com a lei. $\mathrm{O}$ encerramento dado a essa espécie de evangelho abolicionista é mais uma forma de conselho e de vivência de quem nunca havia sido escravizado. $\mathrm{O}$ autor não sabia o que era o pior de tudo: ser propriedade de outro.

Na verdade, as resistências à aplicação da lei não ocorreram apenas nas províncias distantes, como a do Maranhão, por exemplo. $\mathrm{Na}$ Corte, as notícias a esse respeito foram relativizadas nos jornais que se preocuparam com a euforia da liberdade e das suas festas. O cronista parecia estar atento à superficialidade da ideia de harmonia e consenso presente na lei e na sua aceitação. Porém, os leitores do seu evangelho receberam o "boas-noites", forma como se despedia, sabendo o que era o melhor, mas sem saber, de fato, se isso chegara a todos.

Para além da produção de crônicas e do comparecimento aos festejos oficiais, os literatos da Corte também foram convocados pelos organizadores das festas a produzirem poesias feitas especialmente para a ocasião. A intenção seria distribuir os papéis com os escritos poéticos numa matinê literária, que ocorreria num teatro da cidade, e pelas ruas da Corte durante os préstitos. As poesias aparecem nesse contexto festivo como fruto da relação desses poetas com a sociedade escravista, com a campanha abolicionista e com o resultado da Abolição do 13 de maio. Esses escritos, somados às crônicas, alimentaram a memória da Abolição e marcaram o sentido liberal que aquele ato político representava. Essa literatura fez parte do mesmo processo de 
construção de uma memória unívoca da festa, empreendida pelos homens das letras desde a organização dos festejos até a reprodução desses sentidos em forma escrita.

Os papéis coloridos com os poemas escritos por Machado de Assis e Arthur de Azevedo, dentre outros, mediam $25 \mathrm{~cm}$ de altura e 16,5 cm de largura, de modo a chamar a atenção do público e servir como uma espécie de souvenir da festa ${ }^{9}$ - a ser guardado para a posteridade. Seus versos tinham como função criar uma narrativa dos acontecimentos que precederam a assinatura da lei e materializar imagens e sentidos daquele ato. As temáticas variadas escolhidas por seus autores, para explicar o processo abolicionista e apresentar seus responsáveis, definiram também o que deveria ser esquecido e lembrado daquele dia em diante.

Algumas foram distribuídas, no dia 17, das redações dos jornais na rua do Ouvidor e, na noite seguinte, foram distribuídos os versos de Machado de Assis, Rodrigo Otávio, Valentim Magalhães e Soares Sousa Júnior.

Machado de Assis começou com uma referência a todos os brasileiros incluindo diretamente na definição aqueles que, até a véspera, estariam longe de qualquer veleidade de cidadania. Como não havia mais a divisão entre escravos e senhores, todos que antes se dividiam em falanges opostas no regime escravista deviam agora estar juntos na tarefa de construir o futuro da nação através do trabalho. O 13 de maio é, assim, saudado por Machado de Assis como o marco do início dessa união, que configurava verdadeiramente a nação. Novamente aparecem as referências citadas durante os dias de festa nos jornais da Corte, e até de outras províncias, de que o trabalho deveria ser o destino dessa população libertada pela lei. O discurso da imprensa para narrar os préstitos das crianças, ${ }^{10}$ por exemplo, no qual a utilidade da lei é

\footnotetext{
${ }^{9}$ Atualmente esses poemas fazem parte do acervo do Arquivo Público Mineiro. Um envelope com vinte e nove poesias foi doado ao diretor do Arquivo, José Pedro Xavier da Veiga, em 1896, por Joaquim Fróis Vieira Pisco com a seguinte anotação: "Coleção completa das poesias distribuídas durante o trajeto da memorável procissão cívica, em homenagem à Lei de 13 de maio, realizada no Rio de Janeiro no dia 20 de maio de 1888. A coleção completa é raríssima". Não é possível saber o volume de poemas que foram distribuídos nesses festejos, nem se esses folhetos representam a coleção completa a que o autor da nota no envelope se refere. MIRANDA, Poesia, História e circunstância, p. 15; SILVA, Sobre versos, bandeiras e flores, p. 18.

${ }^{10} \mathrm{~A}$ imprensa fluminense organizou dois grandes préstitos: um no domingo, mais diversificado e outro no sábado, dia 19, apenas com os colégios da cidade. Nesse préstito também compareceram os filhos da Princesa Isabel. "O préstito das crianças", Gazeta de Notícias, 20 de maio de 1888. Sobre os préstitos da Abolição ver o capítulo “Abolição em desfile” em MORAES, As festas da abolição.
} 
vinculada ao trabalho, é reforçado nessa poesia de Machado de Assis, que também frequentava o ambiente das redações de onde saíram os relatos das festas.

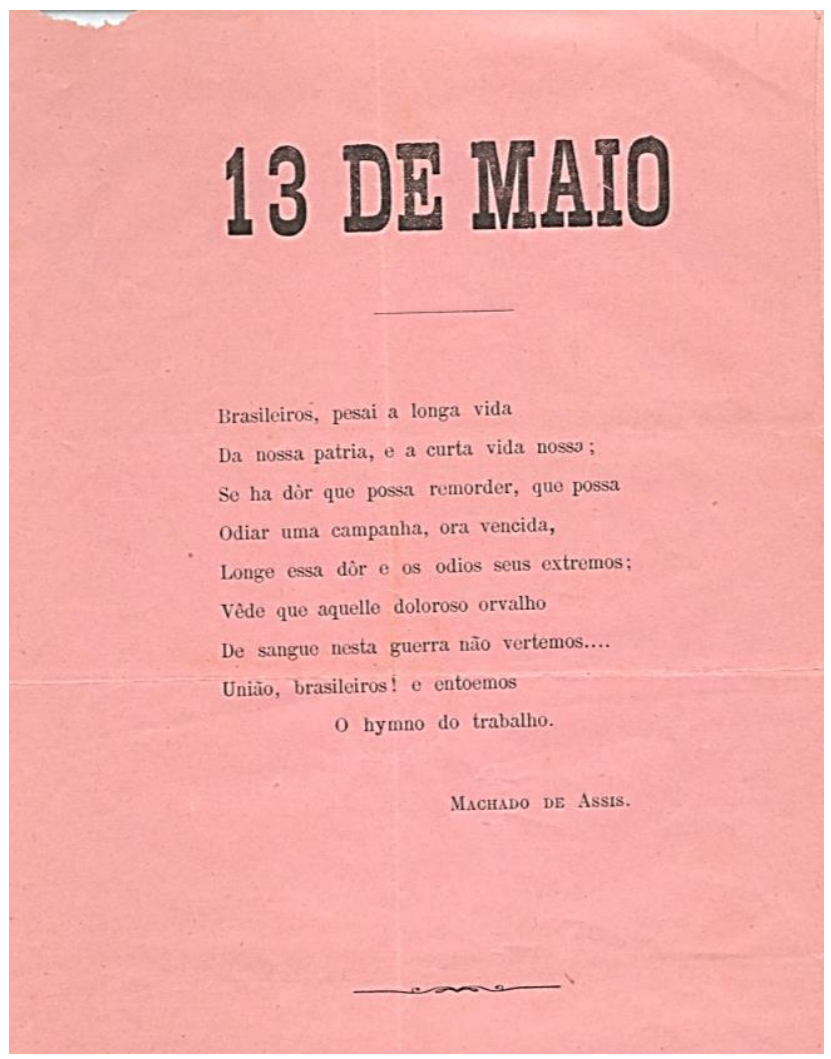

Figura 3 Machado de Assis, 13 de maio, 1888

Além dos poemas, as crônicas publicadas nos grandes jornais na semana da assinatura da Lei privilegiaram a festa como assunto principal. Seus autores trataram de representar na escrita aquilo que viveram no cotidiano das comemorações. Já os poemas possuem uma dinâmica diferente. Menos ligados ao vivido, à referencialidade, eles aparecem como um meio de expressar o que seria a essência da comemoração. Quem ouviu seus autores recitando das sacadas das redações ou compareceu à matinê literária pôde perceber que esses poetas pretendiam usar seus versos como meio de definir um sentido para a Abolição, cujo significado geral se propunham representar.

O contato mais direto desses literatos com o público das ruas ocorreu nos préstitos organizados pela imprensa para encerrar a festa da Abolição. No domingo, 20 de maio, um grande cortejo percorreu várias ruas localizadas entre o Senado da Câmara, no Campo de Santana, e o Largo do Paço, mas sem fazer um percurso reto ou econômico. Pelo contrário, era preciso dar voltas 
em ruas e aumentar o caminho para fazer chegar ao máximo de pessoas o roteiro que pretendiam expor naquela interpretação sobre a Abolição. Se a missa ligava diferentes sujeitos responsáveis pela Abolição, os préstitos ligariam vários pontos da cidade na narrativa daquela história. A comissão da imprensa, a mesma que projetara toda aquela semana de festejo que então se encerrava, abriu o préstito para que aqueles que aderiram ao seu chamado também desfilassem naquele cenário de festa.

Um carro com alguns homens da imprensa abriu o desfile e durante o préstito outros embarcaram, numa espécie de intervalo entre uma ala e outra. Foi o que aconteceu com a passagem dos representantes do Jornal do Commercio, que vieram depois de um batalhão do Exército. Logo em seguida, veio o carro alegórico "A caridade não tem pátria", que precedeu a passagem da "terceira comissão da imprensa", citada assim na Gazeta de Notícias. Essa comissão tinha como guia, ou melhor, como ponta da ala, o abolicionista José do Patrocínio, que desfilava a cavalo juntamente com seu filho. Além dele, também estavam os representantes do Diário Mercantil, de São Paulo, do Cidade do Rio e da Confederação Abolicionista. Essa espécie de bloco, ainda na metade do desfile, aparecia como interrupção de um roteiro. Se antes deles passaram sociedades carnavalescas, abolicionistas, estrangeiras e escolar, em determinado momento do préstito o público que assistia a ele devia se lembrar dos responsáveis não só por aquele evento, mas também do protagonismo vivido pela imprensa na promoção do fim da escravidão. Mostravam-se, assim, caridosos por uma causa que parecia não ter pátria; ou seja, a liberdade era festejada por todos.

O relato do Cidade do Rio descreve a "marcha triunfal da liberdade":

Tudo participava do regozijo pátrio, - o soldado, a defesa do corpo, o padre, a defesa da alma, - o homem que segue para o passado e a criança que olha para o futuro [...] toda a gente se fez representar - o velho que esqueceu o passo e a criança que ainda não o conheceu - o negro e o branco, e o pobre e o rico. E essa promiscuidade imponente desfilou pela cidade em festa maravilhosa e grande como uma procissão olímpica de vitoriosos. ${ }^{11}$

Após cinco anos desse festejo, Machado de Assis sobre isso escrevia:

${ }^{11}$ AS FESTAS da igualdade, 23 maio 1888, grifos meus. 
Houve sol, e grande sol, naquele domingo de 1888, em que o Senado votou a lei, que a regente sancionou, e todos saímos à rua. Sim, também eu saí à rua, eu o mais encolhido dos caramujos, também eu entrei no préstito, em carruagem aberta, se me fazem favor, hóspede de um gordo amigo ausente; todos respiravam felicidade, tudo era delírio. Verdadeiramente, foi o único dia de delírio público que me lembra ter visto. ${ }^{12}$

O delírio de Machado de Assis estava representado nesse préstito do momento em que todos saíram e compartilharam os diferentes sentidos daquela delirante Abolição. No entanto, sua presença na festa e o respiro de felicidade também têm relação com a outra função exercida por ele naquele período. Além de atuar nos jornais da imprensa fluminense, Machado ocupava um cargo no Ministério da Agricultura, junto com Artur de Azevedo. Nesse período, o campo do funcionalismo público, apesar de não ser regulamentado, era local de aquisição de renda fixa, além de prestígio social, uma vez que esses trabalhadores estavam acima dos demais, como caixeiros, artesãos e agregados, por exemplo. ${ }^{13}$

O Ministério da Agricultura era o responsável pela realização das matrículas dos escravos, prevista na lei de setembro de $1871 .{ }^{14} \mathrm{Em} \mathrm{1888 \text {,o }}$ ministro era Rodrigo Silva, também responsável pela apresentação do projeto da lei da Abolição à Câmara. ${ }^{15}$ Nas vésperas do início dos festejos, os funcionários do Ministério prestaram homenagens ao Ministro na ocasião da sua chegada na manhã do dia 16 de maio. ${ }^{16} \mathrm{O}$ chefe da seção, Machado de Assis, ${ }^{17}$ comandou a homenagem com um discurso para todos os presentes, funcionários e Ministro, destacando as ações de Rodrigo Silva e, ao término da sua fala, declarou a admiração sentida por todos ali presentes pela última ação empreendida por Silva: o referendo dado à "lei que declarou para sempre extinta a escravidão no Brasil". ${ }^{18}$ Ao final da cerimônia, que contou também com a banda do Arsenal de Guerra, o Ministro discursou agradecendo a

\footnotetext{
${ }^{12}$ ASSIS, A Semana, 14 maio 1893.

${ }^{13}$ CANDIDO, Um funcionário da Monarquia, p. 11; MAGALHAES JR., Artur Azevedo e sua época, p. 56.

${ }^{14}$ CHALHOUB, Machado de Assis, historiador, p. 207.

${ }^{15} \mathrm{O}$ deputado Rodrigo Silva assumiu o Ministério em maio de 1887 na ocasião da saída de Antonio Prado. MORAES, A campanha abolicionista (1879-1888), p. 144.

${ }^{16}$ ABOLIÇÃO, 17 maio 1888. O Diário de Notícias e o Cidade do Rio também publicaram a notícia da homenagem a Rodrigo Silva

${ }^{17}$ Machado de Assis ingressou no Ministério da Agricultura, Comércio e Obras públicas aos 33 anos de idade. Entrou para o setor como amanuense, no ano de 1873, e, naquela ocasião, já era escritor de certo renome, tendo publicado alguns livros. Logo depois foi nomeado para o cargo de "primeiro oficial". MAGALHÃES JR., Machado de Assis, funcionário público, p. 13, 16.

${ }^{18}$ ABOLIÇÃO, 17 maio 1888.
} 
homenagem e lembrou que o mérito cabia igualmente aos funcionários daquele setor. $\mathrm{O}$ fato é que, desde muito antes de Rodrigo Silva assumir o cargo, foi nesse Ministério, mais especialmente na segunda seção chefiada por Machado de Assis desde 1876, que o trabalho de cumprimento da lei de 1871 foi feito de forma mais rígida, apesar dos protestos de donos de escravos que procuravam brechas na lei a fim de permanecerem com a escravização de homens e mulheres, mesmo com a tentativa de regulação dos escravos existentes no país proposta em um dos artigos da lei. ${ }^{19}$ A manhã especial da quarta-feira no Ministério da Agricultura terminou com a leitura de uma poesia feita por Artur de Azevedo no verso de um cartão de visita:

Conselheiro, perdoai tanta ousadia, Minha falta esqueçai, se há n'isso falta;

Mas vós, firmando a lei que a pátria exalta

Fizestes igualmente uma poesia,

É muito natural que n'este dia,

Que de prazer as almas sobressaltam,

Os prosaicos ofícios tenham alta;

E entrem as musas na secretaria.

Os mesmos sentimentos delicados

Que hoje dão direito a honrada lenda,

Oh! Providência dos escravizados!

Apelo e o vosso coração nos atenda!

Estendei para os vossos empregados

A mão que a liberdade referenda! ${ }^{20}$

Os versos de Artur de Azevedo ironizam a liberdade referendada por Rodrigo Silva, ao mesmo tempo que exaltam a importância do seu ato. Por isso, Artur de Azevedo e os demais funcionários se apresentam como dignos de receber uma "liberdade" - nesse caso, a folga nos dias seguintes, cheios de festejos na Corte, que também, em parte, eram organizados por Azevedo. $\mathrm{O}$ pedido de folga se justificava por ser aquele momento vivido por todos como algo único na história do país e ainda tendo sido prenunciado por um dos membros desse setor. Ou seja, a participação nas festas era uma manifestação

\footnotetext{
${ }^{19}$ Além de determinar a matrícula de todos os escravos, a lei de 1871 também regulava a possibilidade de o escravo adquirir sua liberdade por meio de pecúlio. Tal possibilidade abriu margens para que houvesse ainda mais batalhas na Justiça pela liberdade dos escravos por meio do uso da lei. MENDONÇA, Cenas da Abolição, p. 55.

${ }^{20}$ ABOLIÇÃO, Gazeta de Notícias, 17 maio 1888. Essa poesia também foi publicada por Magalhães Júnior em sua biografia de Artur Azevedo (MAGALHÃES JR., Artur Azevedo e sua época, p. 147).
} 
de civismo da qual não pretendiam ausentar-se. A resposta de Rodrigo Silva foi positiva ao pedido feito em forma de verso, e com um "até segunda" liberou seus funcionários para curtirem aqueles dias de festa. ${ }^{21}$

No entanto, Machado de Assis e Artur de Azevedo estavam dentro da dinâmica da realização das festas da imprensa, uma vez que, além da atuação no Ministério, também colaboravam nos jornais membros da comissão. Ao mesmo tempo, a folga reivindicada por Artur de Azevedo promoveu também a liberação dos demais funcionários que puderam viver aqueles dias em sua plenitude.

No relato dessa homenagem feito pelos jornais da Corte, Machado de Assis e Artur de Azevedo não eram os únicos a serem reconhecidos por suas atuações no Ministério. Os demais que exerciam apenas esse ofício também foram destacados pelo editor do Cidade do Rio para justificar as homenagens recebidas não apenas por Rodrigo Silva, mas por todos que ao lado dele trabalharam.

No silêncio do gabinete, José Júlio, Amarillo de Vasconcelos, Machado de Assis, Pinto Serqueira, Paula Barros, e ainda outros, dedicaram-se durante anos a velar com solicitude na defesa dos direitos dos escravos, a tirar das leis de liberdade todos os seus naturais corolários, a organizar e a tornar efetiva a emancipação gradual pela ação do Estado [...]. ${ }^{22}$

Ao citar o nome de funcionários que, no cumprimento de suas funções, haviam se dedicado à defesa dos "direitos dos escravos" - expressão reveladora do sentido político de suas ações -, o jornal mostrava como muitos daqueles funcionários da Secretaria tinham efetivamente trabalhado para o fim da escravidão ao regularem as relações entre senhor e escravo a partir dos princípios previstos em lei. ${ }^{23} \mathrm{E}$ o que mostra, em especial, o caso de Machado de Assis. Após assumir o cargo de funcionário do Ministério em 1873, três anos depois ele passou a chefiar a seção encarregada de acompanhar a aplicação da lei de 1871. Os pareceres escritos por ele a favor do cumprimento da lei na sua forma total mostram a crença desse funcionário na validade da legislação como um passo importante para a emancipação dos escravos. Além da produção de pareceres duros e contrários à manutenção da escravização de homens e mulheres não matriculados, o escritor também utilizava, nesse

${ }^{21}$ GAZETA DE NOTÍCIAS, 17 maio 1888.

22 MANIFESTAÇÃO honrosa, 18 maio 1888.

${ }^{23}$ CHALHOUB, Visões da liberdade; MENDONÇA, Cenas da Abolição. 
período, o campo da crônica para elogiar os efeitos da lei. ${ }^{24} \mathrm{O}$ engajamento de funcionários públicos como Machado de Assis na causa dos escravos explica, portanto, o sentido tanto da homenagem oferecida ao Ministro quanto da folga que lhes foi permitida por ele, uma vez que esses trabalhadores são vistos como agentes daquilo que se festejava em maio de 1888. A liberdade conquistada no dia 13 de maio, não como uma dádiva, como faziam crer alguns editores dos jornais da Corte, deveria ser celebrada na sua plenitude como uma conquista iniciada décadas antes no parlamento e na justiça.

A Abolição em 1888 foi vivida por Machado de Assis plenamente nas festas e nos seus escritos, assim como por outros literatos do período, sendo a sua celebração um modo de sintetizar sentimentos e sensações sobre a liberdade que pareciam esparsos e ainda em construção.

Após cinco anos desse acontecimento, muita coisa mudara, principalmente no cenário político. O dia 13 de maio de 1893 ganhava novas cores e novos atores, e a imprensa, mesmo com alguns abolicionistas ainda atuando, tinha outro foco de ação. A República criara novas questões para esses antigos abolicionistas, e as festas da Abolição já não tinham a função de outrora. Esse é o mote para a escrita de outra crônica machadiana que tem a Abolição como tema principal. Na verdade, a sua memória em eterna construção.

No dia 14 de maio de 1893, a Gazeta de Notícias publicou uma crônica de Machado de Assis que se iniciava com o relato da véspera, quando se celebrara o aniversário da Abolição:

Ontem de manhã, descendo ao jardim, achei a grama, as flores e as folhagens transidas de frio e pingando. Chovera a noite inteira; o chão estava molhado, o céu feio e triste, e o Corcovado de carapuça. Eram seis horas; as fortalezas e os navios começaram a salvar pelo quinto aniversário do Treze de Maio. Não havia esperanças de sol; e eu perguntei a mim mesmo se o não teríamos nesse grande aniversário. É tão bom poder exclamar: "Soldados, é o sol de Austerlitz!". O sol é, na verdade, o sócio natural das alegrias públicas; e ainda as domésticas, sem ele, parecem minguadas. ${ }^{25}$

Marcada pela melancolia, esta nota inicial não deixava dúvidas sobre o estado de espírito do cronista. Por mais que o quinto aniversário da Abolição começasse com salvas de tiro dadas pelos navios ancorados na baía de

${ }^{24}$ CHALHOUB, Machado de Assis, historiador, p. 288-9.

${ }^{25}$ ASSIS, A Semana, 14 maio 1893. 
Guanabara, parte dos festejos oficiais do regime republicano para celebrar a data, tratava-se para ele de um dia "feio e triste". O tempo, nublado e frio, era bem distinto daquele que vivera cinco anos antes, cujas lembranças aparecem na continuação da crônica: "[...] Houve sol, [...] Verdadeiramente, foi o único dia de delírio público que me lembra ter visto".

Nas memórias do literato, o sol do dia 13 de maio de 1888 ajudou a compor um cenário de festa, cuja claridade era proporcional ao entusiasmo geral. Incluindo-se no rol dos que festejavam o ato, justifica-se por ser aquele um dia de "delírio público" de todo singular. Era assim, como uma ocasião de verdadeiro entusiasmo generalizado, que Machado de Assis rememorava a data celebrada.

As festas pela Abolição aparentemente não provocavam o mesmo entusiasmo de outrora e, aos olhos dos contemporâneos, parecia já uma lembrança distante o regozijo público e geral das festas de maio de 1888. É como um testemunho desse processo que podemos entender o sentido da crônica escrita por Machado de Assis em maio de 1893. Ela deixava claro como, nesse momento, o 13 de maio já não representava para ele a celebração das luzes da liberdade, antes pelo contrário: era então em um cenário sombrio que se celebrava novamente a data. Na sua crônica após o aniversário da Abolição, a política e o seu encaminhamento eram as causas para esse passado que parecia ignorado naqueles dias.

Um velho autor da nossa língua, - creio que João de Barros; não posso ir verificá-lo agora; ponhamos João de Barros. Este velho autor fala de um provérbio que dizia: "os italianos governam-se pelo passado, os espanhóis pelo presente e os franceses pelo que há de vir". E em seguida dava "uma repreensão de pena à nossa Espanha", considerando que Espanha é toda a península, e só Castela é Castela. A nossa gente, que dali veio, tem de receber a mesma repreensão de pena; governa-se pelo presente, tem o porvir em pouco, o passado em nada ou quase nada. Eu creio que os ingleses resumem as outras três nações. ${ }^{26}$

A reflexão que Machado de Assis faz após o seu testemunho das festas é de que a política republicana seguia o mesmo da feita pela Espanha, onde o passado e o futuro não interessavam. O governo devia ser pelo presente e nada mais. O passado de busca por uma liberdade não precisaria ser louvado num ambiente político que pensava no presente, ignorando toda uma trajetória histórica de conquista da liberdade. Nesse sentido, o tipo de celebração da data

${ }^{26}$ Idem. 
promovida pela República, com afirmações de fraternidade e salvas de tiro, seriam simples marcas de uma celebração do presente que ignorava o peso e o sentido histórico da data celebrada.

Tendo escrito sua crônica no dia da festa, Machado de Assis parecia espelhar, nela, as celebrações oficiais que testemunhava. Sem muitas novidades, o quinto aniversário da Abolição repetia a lógica e a forma dos anos anteriores. Os edifícios públicos foram iluminados, e a estação da Estrada de Ferro Central recebeu uma banda de música e uma iluminação especial. Os teatros também reservaram espetáculos diferenciados para celebrar a lei, e a rua Senador Dantas, além de ser iluminada de forma diversa do dia a dia, recebeu um coreto de uma fábrica de cerveja. ${ }^{27}$ A fim de facilitar o deslocamento de sociedades musicais do subúrbio para a cidade, a Estação Central concederia entradas gratuitas para os membros dessas sociedades. ${ }^{28}$ Houve também festas realizadas pela Irmandade do Rosário de São Benedito, ${ }^{29}$ e em São Cristóvão as celebrações ficaram por conta da Irmandade do Nosso Senhor do Bonfim e N. S Paraíso, com o lançamento de fogos de artifício e coreto no adro da igreja. ${ }^{30}$ Toda essa programação mostra que havia uma movimentação em torno da data, mesmo que a repercussão da adesão pública a ela não fosse feita de forma sistemática pelos jornais. Ou seja, apesar de haver festa, não sabemos nada além da sua realização. ${ }^{31}$

Não era de se estranhar, por isso, que o desânimo de Machado de Assis pelas festas do 13 de maio de 1893 fosse reiterado por alguns jornais da capital federal. N'O Paiz, o entusiasmo do editor pelas festas parece ter mudado conforme passou o dia. Na véspera do aniversário, ao divulgar a programação do dia seguinte, afirmara que se revelava "no seio da população fluminense um justo entusiasmo pelas festas que serão realizadas amanhã, comemorativas da lei de 13 de maio, início das liberdades públicas do Brasil". ${ }^{32}$ No entanto, não considerou esse mesmo entusiasmo ao relatar como a data havia sido celebrada: "sem grandes demonstrações de público regozijo passa hoje uma das maiores datas que a história pátria registra". ${ }^{33}$ Ao contrário da população que parecia permanecer com seu entusiasmo em torno da festa, as manifestações oficiais em torno da celebração do treze de maio pareciam cada

\footnotetext{
27 AS FESTAS de ontem, 14 maio 1893.

${ }^{28} 13$ DE MAIO, 12 maio 1893.

29 DIÁRIO DE NOTÍCIAS, 13 maio 1893.

30 AGCRJ, Códice 43,3,75. Festejos religiosos pela data da lei que extinguiu a escravidão no Brasil Igreja do Bonfim e N. S. do Paraíso.

${ }^{31}$ AS FESTAS de ontem, 14 maio 1893.

3213 DE MAIO, 12 maio 1893.

${ }^{33}$ Idem.
} 
vez mais reduzidas. Assim como fez o Diário de Notícias no relato da festa, $O$ Paiz não ofereceu aos seus leitores maiores informações sobre a adesão popular aos festejos programados. Permanecendo, assim, a ideia de que as festas pela Abolição caíam num vazio de sentidos e de adesão pública.

O desânimo de Machado de Assis era também compartilhado por um leitor do Diário de Notícias que enviou um artigo ao jornal a respeito da data, reclamando que as festas pela Abolição haviam ocorrido sem a menção aos nomes de alguns abolicionistas importantes, como José do Patrocínio, Julio de Lemos, Luiz de Andrade, Antonio Azeredo e João Clapp. ${ }^{34} \mathrm{O}$ autor termina o texto com ênfase sobre o esquecimento operado nos dias de festa:

Estranhável, repito, que nas festas da Abolição sejam omitidos os nomes de alguns dos mais dignos e ilustres generais d'essa campanha - nomes tão intimamente ligados ao 13 de maio, que festejar a Abolição sem os honrar é fazer uma exclusão [...] seguramente inexplicável. ${ }^{35}$

A sua conclusão a respeito das festas mal esconde seu descontentamento com a forma como o novo regime recém-instaurado passara a celebrar a data. Se afirmava não ver os abolicionistas serem celebrados, mesmo sendo lembrados em eventos particulares, desligados de qualquer lógica oficial e pública, incomodava ao missivista a releitura da História promovida pela República, que tentava recriar arbitrariamente os sentidos da festa. Como Machado de Assis, era do esquecimento do passado, tentativa de calar a história de muitos sujeitos envolvidos com a festa, que ele reclamava em sua mensagem. Parece explicável, por isso, que na continuação de sua crônica Machado de Assis associasse as novas comemorações do 13 de maio às festas da independência, que já haviam caído no esquecimento e não possuíam mais a força e a importância que tiveram em sua infância.

Temo que o nosso regozijo vá morrendo, e a lembrança do passado com ele, e tudo se acabe naquela frase estereotipada da imprensa nos dias da minha primeira juventude. Que eram afinal as festas da independência? Uma parada, um cortejo, um espetáculo de gala. Tudo isso ocupava duas linhas, e mais estas duas: as fortalezas e os navios de guerra nacionais e estrangeiros surtos no porto deram as salvas de estilo. Com este pouco, e

\footnotetext{
${ }^{34}$ Luiz de Andrade e Antonio Azeredo participaram da confederação abolicionista. SILVA, As camélias do Leblon e a abolição da escravatura.

35 TREZE de maio, 10 maio 1893. O texto possivelmente foi enviado à redação do jornal, já que está entre aspas e precedido de "escrevem-nos".
} 
certo, estava comemorado o grande ato da nossa separação da metrópole. ${ }^{36}$

A perda do regozijo que o literato teme é o perigo que sentia correr a festa da Abolição: de grande festejo para uma parada cívica sem povo e sem sentido. A experiência do literato com as festas pela independência levava a crer que o mesmo poderia acontecer com o festejo da Abolição, que na República se esvaziava de sentido. Ao citar a lembrança do passado, o literato na verdade está temendo uma descaracterização da festa por parte de quem seria responsável pela sua promoção, o regime republicano. O tempo feio que fazia era uma resposta à frieza do esquecimento que tal data vinha sofrendo.

Portanto, os aniversários da Abolição seriam feitos, na República, a partir de uma conjuntura política específica que acabou por tentar afastar a festa de seus sentidos e sujeitos originais - fossem as lideranças abolicionistas ligadas à Coroa ou os próprios ex-escravos. Por outro lado, a cada ano vinha sendo apropriada por aqueles que, independente de parâmetros oficiais, continuavam a celebrar os sujeitos do passado, os abolicionistas e a Princesa. Para esses festeiros, a data do 13 de maio era a da abolição da escravidão e assim deveria ser celebrada. Na crônica de Machado de Assis, a defesa por essa celebração se reafirma principalmente ao tentar trazer do passado um período de glória e de grandes festividades pela data. Para o literato, testemunha das festas de 1888, a essência das comemorações não deveria ser perdida, apesar de um esforço oficial para que isso acontecesse. Ao final da crônica deixa claro o seu desejo, entre as rabugices de um velho escritor:

Não, não. O triste sou eu. Provavelmente má digestão. Comi favas, e as favas não se dão comigo. Comerei rosas ou primaveras, e pedir-vos-ei uma estátua e uma festa que dure, pelo menos, dois aniversários. Já é demais para um homem modesto. ${ }^{37}$

A tristeza do literato e a falta de flores se ligavam, portanto, à indiferença em relação à festa, que o entristecia e causava má digestão. Ao escrever a crônica em 1893, percebe que as celebrações que testemunhara nos cinco aniversários da Abolição não foram suficientes para satisfazer a sua vontade de festejar a data. As festas das suas lembranças, que deveriam ser modelo para as dos anos seguintes, não haviam durado além daquele dia de delírio de 1888 .

\footnotetext{
${ }^{36}$ ASSIS, A Semana, 14 maio 1893.

${ }^{37}$ Idem.
} 
A República, de fato, parecia não perpetuar os sentidos da data, muito menos o sol da liberdade vivido por ele naquele dia da Abolição.

\section{Referências}

ABOLIÇÃO, Gazeta de Notícias, 17 maio 1888.

AGCRJ, Códice 43,3,75. Festejos religiosos pela data da lei que extinguiu a escravidão no Brasil - Igreja do Bonfim e N. S. do Paraíso. São Cristóvão, 1893.

ALONSO, Angela. Flores, votos e balas. São Paulo: Companhia das letras, 2015.

AS FESTAS da igualdade. Cidade do Rio, 23 maio 1888.

AS FESTAS de ontem. Diário de Notícias, 14 maio 1893.

ASSIS, Machado de. A Semana, Gazeta de Notícias, 14 maio 1893.

CANDIDO, Antonio. Um funcionário da Monarquia. Ensaio sobre o segundo escalão. Rio de Janeiro: Ouro Sobre Azul, 2002.

CHALHOUB, Sidney. Machado de Assis, historiador. São Paulo: Companhia das Letras, 2003.

. Visões da liberdade. Uma história das últimas décadas a escravidão na corte. São Paulo: Companhia das Letras, 1990.

DIÁRIO DE NOTÍCIAS, 17 maio 1888; 13 maio 1893.

GLEDSON, John (org.). Bons Dias! - Machado de Assis. São Paulo: Hucitec, 1990.

LAGO, Pedro; LAGO, Bia Corrêa. Coleção Princesa Isabel. Fotografia do século XIX. Rio de Janeiro: Capivara Editora, 2008.

MAGALHÃES JR., Raimundo. Artur Azevedo e sua época. Rio de Janeiro: Civilização Brasileira, 1966.

. Machado de Assis, funcionário público (No Império e na República). Rio de Janeiro: Ministério da Viação e Obras Públicas - Serviço de Documentação, 1958. MANIFESTAÇÃO honrosa. Cidade do Rio, 18 maio 1888.

MELlO, Maria Tereza Chaves. A República consentida. Cultura democrática e científica do final do Império. Rio de Janeiro: Editora FGV/Edur, 2007.

MENDONÇA, Joseli Nunes. Cenas da Abolição. Escravos e senhores no parlamento e na justiça. São Paulo: Fundação Perseu Abramo, 2001.

MIRANDA, José Américo. Poesia, História e circunstância. In: Maio de 1888. Poesias distribuídas ao povo, no Rio de Janeiro, em comemoração à Lei de 13 de maio de 1888. Rio de Janeiro: Academia Brasileira de Letras, 1999.

MORAES, Evaristo de. A campanha abolicionista (1879-1888). 2 ed. Brasília: Editora Universidade de Brasília, 1986.

MORAES, Renata Figueiredo. As Festas da Abolição. O 13 de maio e seus significados no Rio de Janeiro (1888-1908). Tese de Doutorado, História Social da Cultura, PUCRio, 2012.

O PRÉSTITO das crianças. Gazeta de Notícias, 20 maio 1888. 
OCTAVIO, Rodrigo. 13 de Maio de 1888, Diário de Notícias, 14 maio 1888, p. 1.

RABELO, Pedro. Treze de Maio. Diário de Notícias, 14 maio 1888, p. 1.

REGADAS, Theotonio Diniz. 13 de Maio de 1888. Diário de Notícias, 14 maio 1888, p. 1.

SILVA, Eduardo. As camélias do Leblon e a abolição da escravatura. Uma investigação de História cultural. São Paulo: Companhia das Letras, 2003.

Sobre versos, bandeiras e flores. In: VENÂNCIO, Renato Pinto (org.). Panfletos abolicionistas. O 13 de maio em versos. Belo Horizonte: Secretaria de Estado de Cultura de Minas Gerais, Arquivo Público Mineiro, 2007.

TREZE de maio. Diário de Notícias, 10 maio 1893.

13 DE MAIO. O Paiz, 12 maio 1893.

13 DE MAIO. O Paiz, 13 maio 1893.

RENATA FIGUEIREDO MORAES é professora adjunta de História do Brasil do Departamento de História da Universidade do Estado do Rio de Janeiro, UERJ. E-mail: renatafmoraes@gmail.com. 